Article

\title{
Comparison of Bioactive Substances Content between Commercial and Wild-Type Isolates of Pleurotus eryngii
}

\author{
Antonella Calabretti ${ }^{1}$, Stefania M. Mang ${ }^{2}{ }^{*} \mathbb{D}$, Antonella Becce ${ }^{2}$, Donato Castronuovo ${ }^{2} \mathbb{D}$, Loriana Cardone ${ }^{2} \mathbb{D}$, \\ Vincenzo Candido $^{3}$ (D) and Ippolito Camele ${ }^{2}$ (D) \\ 1 Department of Chemical and Pharmaceutical Sciences, Piazzale Europa 1-Via Giorgieri 1, University of \\ Trieste, 34127 Trieste, Italy; antonella.calabretti@deams.units.it \\ 2 School of Agricultural, Forestry, Food and Environmental Sciences (SAFE), University of Basilicata, Viale \\ dell'Ateneo Lucano 10, 85100 Potenza, Italy; antonellabecce@ymail.com (A.B.); \\ donato.castronuovo@unibas.it (D.C.); loriana.cardone@unibas.it (L.C.); ippolito.camele@unibas.it (I.C.) \\ 3 Department of European and Mediterranean Cultures, Environment, and Cultural Heritage, University of \\ Basilicata, Via Lanera 20, 75100 Matera, Italy; vincenzo.candido@unibas.it \\ * Correspondence: stefania.mang@unibas.it; Tel.: +39-097-1205-544
}

\section{check for} updates

Citation: Calabretti, A.; Mang, S.M.; Becce, A.; Castronuovo, D.; Cardone,

L.; Candido, V.; Camele, I.

Comparison of Bioactive Substances

Content between Commercial and

Wild-Type Isolates of Pleurotus eryngii.

Sustainability 2021, 13, 3777.

https://doi.org/10.3390/su13073777

Academic Editors: Marc A. Rosen,

Pietro Santamaria, Giulia Conversa, Antonio Elia and Massimiliano Renna

Received: 15 January 2021

Accepted: 25 March 2021

Published: 29 March 2021

Publisher's Note: MDPI stays neutral with regard to jurisdictional claims in published maps and institutional affiliations.

Copyright: (c) 2021 by the authors. Licensee MDPI, Basel, Switzerland. This article is an open access article distributed under the terms and conditions of the Creative Commons Attribution (CC BY) license (https:/ / creativecommons.org/licenses/by/ $4.0 /)$.

\begin{abstract}
Mushrooms belonging to Pleurotus genus have been demonstrated to have important nutritional and medicinal value and their regular intake prevent many diseases, reduce the infection probability and increase immunity. In order to investigate the bioactive compounds produced by seven commercial ('142 F', '142 E', 'D+', 'V turbo', 'V 142', 'A 12', 'V 160') and five wild-type ('Albino 1107', 'Altamura 1603', 'Muro Lucano 139', 'Conversano 1250', 'Albino beige chiaro 1094’) P. eryngii isolates, the following qualitative analyses were performed: Total polyphenol content, antioxidant activity (EC 50 of ABTS) and antiradical power (ARP) in fresh lyophilized and dry basidioma, and water content, $\beta$-glucans and phenolic compounds in fresh samples. Standard methods were employed for each of the above mentioned aims. Total polyphenol content was diverse among the P. eryngii isolates. In particular, an elevated polyphenolic content was found in fresh lyophilized P. eryngii samples of the commercial isolates ' $\mathrm{V} 142$ ' followed by 'A 12'. The highest antiradical activity (ARP) was obtained by 'Muro Lucano 139 ' isolate. Wild P. eryngii isolates were characterized by higher water and $\beta$-glucans contents compared to the commercial ones, and the highest values were registered for the 'Albino beige chiaro 1094' isolate. In conclusion, the present study allowed us to identify the commercial and wild-type P. eryngii isolates from the Basilicata region, with high nutritional and medicinal value based on their bioactive compounds.
\end{abstract}

Keywords: "King Oyster"; bioactive compounds; qualitative analyses; total polyphenols; glucans; antioxidants

\section{Introduction}

Mushrooms are important functional foods included in the recommended wellbalanced diet [1-6] and in the "Third Food Kingdom" [7,8].

In recent years, many studies have been carried out to identify new compounds from edible mushrooms with biological activity [5,9-12] and pharmacological and medicinal properties $[7,13,14]$.

Among the most cultivated edible fungi, Pleurotus is a particularly interesting genus due to its nutraceutical properties linked to the polysaccharide fraction $[15,16]$, such as $1-3-\beta$-D-glucans (pleuromutilin and pleurane). Other bioactive compounds present in Pleurotus spp. are proteins, peptides and lectins (with high molecular weight), terpenes, fatty acid esters and polyphenols (with low molecular weight) [17]. Many studies on the health effects of Pleurotus species have been reported, such as immune-stimulating activity [18,19], antimicrobial and antiviral [20], hypoglycemic [21-24], anticancer [19,25], 
neuroprotective activities [26,27], hypocholesterolemic [28-31], antineoplastic, hypotensive, anti-inflammatory, antioxidant and hepatoprotective effects [32-34] and anti-allergic properties [35].

Numerous molecules/classes of compounds (proteins, peptides, polysaccharides, lipid derivatives, glycoproteins, etc.) with therapeutic properties have been isolated so far from fungi including Pleurotus spp. Among the polysaccharides, the most abundant are chitin, hemicellulose, $\beta$ and $\alpha$-glucans, mannans, xylans and galactans, and the compounds that stimulated the greatest interest are the high molecular weight polysaccharides. Especially $\beta$-glucans $(\beta-(1,3) \rightarrow(1,6)$-glucans $)$, which interact with the immune system to increase/decrease specific aspects of host response and are; therefore, called biological response modifiers (BRMs) $[36,37]$. The antiviral activity is also due to the strengthening of the host's immune system and to the production of interferons under the stimulus of $\beta$-glucans, and is inhibited by fungal glycoproteins, protein-bound polysaccharide K (PSK), as well as by the $\beta$-glucans themselves $[38,39]$.

In particular, Pleurotus eryngii (DC.) Quél., 1872, known as the "King Oyster" mushroom or "Cardoncello", is considered to be a medicinal mushroom due to its content of high value proteins, vitamins and minerals and the low amount of carbohydrates and cholesterol [20]. A hemolysin called "Eryngeolysin" was isolated from P. eryngii and demonstrated to have particularly good cytotoxicity against leukemic cells and antibacterial activity [40]. "Cardoncello" also produces lovastatin (mevicolin, monacolin K), an important molecule that acts by competitively inhibiting the enzyme 3-hydroxy-3-methylglutaryl coenzyme A reductase (HMG-CoA) [41] and is one of the most potent drugs for lowering blood cholesterol employed so far.

Bioactive compounds are influenced by type of mushroom and some information regarding the chemical characterization of wild and cultivated mushrooms is available in literature. Nutritional composition and positive properties of wild mushrooms from Portugal [11], Khasi Hills of Meghalaya [42], northwest Spain [43] and southern Italy [44] have been reported. Furthermore, very recently, Obodai et al. [45], evaluated the antioxidant properties, composition in minerals, lipophilic and hydrophilic molecules of four cultivated (Lentinus squarrosulus strains SQW and LSF, P. ostreatus strain EM-1, P. sajorcaju strain PScW and Auricularia auricula) and two wild mushrooms (P. tuber-regium and Termitomyces robustus) from Ghana, and they found significant differences between wild and cultivated mushrooms, reporting their relevant nutritional aspect, high antioxidant potential, carbohydrates, proteins and macro- and micro-elements diverse content and generally low fat levels.

Although the glucans and phenolic composition of extracts from Pleurotus species has been quite well documented over the years [11,46-48], there are no studies on the comparison of bioactive substances between commercial and wild P. eryngii in the Basilicata region (Southern Italy). Therefore, the aim of this study was to determine in twelve P. eryngii isolates (seven commercial and five wild) the following parameters: (i) Total Polyphenol Content (TPC) and antioxidant activity in lyophilized fresh and dried samples and, (ii) total amount of $\beta$-glucans in fresh lyophilized samples, to point out fungal isolates with superior nutritional and medicinal value.

\section{Materials and Methods}

\subsection{Fungal Isolation and Culture}

Twelve P. eryngii isolates, commercial and wild-type, originating from the Basilicata region (Southern Italy) were used in this study. The commercial isolates investigated were: '142 F'; '142 E'; 'D+'; 'V turbo'; 'V 142'; 'A 12'; 'V160' and the wild-type fungal isolates were: 'Albino 1107'; 'Altamura 1603'; 'Muro Lucano 139'; 'Conversano 1250' and 'Albino beige chiaro 1094'. Fungal isolates belonged to the Fungal Culture Collection (FCC) of the Mycology laboratory (University of Basilicata, Potenza, Italy) and were stored at $4{ }^{\circ} \mathrm{C}$ as pure cultures, in tubes containing potato dextrose agar (PDA) media. After revitalization on PDA added with $0.5 \mathrm{~g} \mathrm{~L}^{-1}$ streptomycin sulfate, the Petri plates were incubated at 
$22{ }^{\circ} \mathrm{C}$ in the dark. Well-grown mycelia were inoculated on wooden sticks in glass cylinders and placed again in an incubator at $22{ }^{\circ} \mathrm{C}$. Subsequently, standard substrate bags were inoculated with the wooden sticks and positioned in a greenhouse at $25^{\circ} \mathrm{C}$ at about $90 \%$ RH. A randomized block experimental design with three replicates was applied, and each experimental unit included two substrate bags well colonized by mycelium [6]. Mushroom cultivation was performed following the standard technique usually used by farmers. Finally, qualitative analyses were carried out on P. eryngii samples of different isolates.

\subsection{Qualitative Analysis}

Before proceeding with the qualitative analyses, each sample (fresh/dry) was subjected to lyophilization and, subsequently, the extract was obtained from each dry residue. To obtain the extract, $20 \mathrm{~mL}$ of an $80 \%$ methanolic solution was added to $2 \mathrm{~g}$ of mushroom powder and the mixture was left to stir for $30 \mathrm{~min}$ at room temperature (RT). After, the sample was centrifuged, the supernatant was discarded, and the residual pellet was extracted again with another $20 \mathrm{~mL}$ of methanol solution. The liquid phases were then combined and reduced in volume $(20 \mathrm{~mL})$ by means of a Heidolph Hei Vap G1 rotary evaporator (BUCHI, Germany). Finally, the fungal extracts were used in several analyzes to identify: (a) The total polyphenol content (TPC); (b) the antioxidant activity; (c) the phenolic profile; and (d) the content of $\beta$-glucans.

\subsubsection{Determination of Polyphenols by the Folin-Ciocâlteu Method}

To determine the polyphenols, the spectrophotometry method with Folin-Ciocâlteu reagent [49-51] was used and the reagent consisted of an aqueous solution of phosphomolybdate and phosphotungstate. For these analyses, the filtrate obtained previously was diluted at 1:10. Fifty hundred $\mu \mathrm{l}$ of Folin-Ciocâlteu reagent was added to $1 \mathrm{~mL}$ of each sample and after $3 \mathrm{~min} 1 \mathrm{~mL}$ of $10 \%$ sodium carbonate $\left(\mathrm{Na}_{2} \mathrm{CO}_{3}\right)$ was added to the mix in order allow the reaction of the compounds. Then, the total volume was brought to $10 \mathrm{~mL}$ with distilled water and the sample was kept for $1 \mathrm{~h}$ in the dark. After, the absorbance was measured using a UV spectrophotometer (Cary 60, Agilent Technologies, Santa Clara, CA, USA) at $765 \mathrm{~nm}$ wavelength. The results were expressed as the mean value of three repetitions \pm standard error of mean (SEM).

\subsubsection{Analysis of Phenolic Compounds}

The determination of the phenolic profile was performed by high performance liquid chromatography (HPLC) analysis [52,53]. An InfinityLab Poroshell 120 EC-C18 chromatographic column, $4.6 \times 150 \mathrm{~mm}, 4 \mu \mathrm{m}$ (Agilent Technologies, Santa Clara, CA, USA) was used. For the elution, a binary mixture of solvents $\mathrm{A}$ and $\mathrm{B}$ was used, whose compositional and elution characteristics are reported below: Solvent A was $0.1 \%$ formic acid in Milli-Q water; Solvent B was $75 \%$ acetonitrile; flow rate was $1 \mathrm{~mL} \mathrm{~min}^{-1}$; the temperature of the column was kept at $40{ }^{\circ} \mathrm{C}$ and the wavelength was $260 \mathrm{~nm}$. The elution profile is shown in Table 1 . To determine the analytes, the calibration straight lines were prepared using pure reference standards: ferulic acid, gallic acid, epicatechin (ECG) and epigallocatechallallate (EGCG).

Table 1. Elution profile used in the HPLC analysis.

\begin{tabular}{ccc}
\hline Time (min) & $\begin{array}{c}\mathbf{0 . 1} \% \text { Formic Acid } \\
\mathbf{( \% )}\end{array}$ & $\begin{array}{c}\mathbf{7 5 \%} \text { Acetonitrile } \\
\mathbf{( \% )}\end{array}$ \\
\hline 0.00 & 98.00 & 2.00 \\
15.00 & 85.00 & 15.00 \\
25.00 & 85.00 & 15.00 \\
35.00 & 75.00 & 25.00 \\
45.00 & 0.00 & 100.00 \\
50.00 & 0.00 & 100.00 \\
\hline
\end{tabular}




\subsubsection{Antioxidant Activity}

Among the various methods commonly used to determine antioxidant activity, based on the deactivation of a radical whose concentration is known, (ORAC, ABTS, DPPH, reduction of thiobarbituric acid, reduction of Fe, etc.), the ABTS method as described by Miller et al. [54] and usually employed to study P. eryngii antioxidant activity [55-57] was used in this study. This generates the radical starting from the oxidation of the ammonium salt of 2,2-azobis-(3-ethylbenzothiazolin-6-sulphonic acid-ABTS) by means of a solution of potassium persulphate $\mathrm{K}_{2} \mathrm{~S}_{2} \mathrm{O}_{8}$. To $5 \mathrm{~mL}$ of ABTS with $7 \mathrm{mM}$ concentration, $88 \mu \mathrm{L}$ of $\mathrm{K}_{2} \mathrm{~S}_{2} \mathrm{O}_{8}, 140 \mathrm{mM}$, was added. Then, the solution was allowed to react for $16 \mathrm{~h}$ in the dark in order to obtain and stabilize the radical cation (ABTS $\bullet$ ). To proceed with the analysis, the solution measured at a wavelength of $734 \mathrm{~nm}$ was diluted with ethanol up to an absorbance of $0.70 \pm 0.02$. When the radical solution, with its intense green-blue color, is put into contact with the active extracts, the antioxidant compounds present cause its discoloration, whose intensity reduction is then measured with a spectrophotometer at $734 \mathrm{~nm}$. The determinations were made at a steady-state (tss) time of $30 \mathrm{~min}$. This discoloration was proportional to the antioxidant charge present in the sample and was calculated as a percentage of absorbance decrease, called "inhibition percentage" (I\%). This parameter was calculated using the following formula (1):

$$
I(\%)=\frac{\text { Abs ABTS-Abs sample }}{\text { Abs ABTS }} \times 100
$$

where: Abs ABTS = the absorbance of the ABTS and Abs = the absorbance of the sample. To determine the $\mathrm{I}(\%)$ of each extract, four dilutions were prepared in ethanol, in a concentration range 0.4-20.4. For each solution, $100 \mu \mathrm{L}$ was taken and $900 \mu \mathrm{L}$ of ABTS $\bullet$ was added. Then, the absorbance was measured at the tss and the I $(\%)$ calculated. A straight line was used to calculate the percentage of inhibition, from which it was possible to extrapolate the value of $\mathrm{EC}_{50}$ (the value at which the inhibition of $50 \%$ of the concentration observed of the radical $\mathrm{ABTS})$.

\subsection{4. $\beta$-Glucans Extraction}

For the extraction of $\beta$-glucans, the method of Lee et al. [58] with minor modifications was used. To $2 \mathrm{~g}$ of dry mushroom extract, $20 \mathrm{~mL}$ of a $2 \% \mathrm{NaOH}$ solution was added and then heated at $90^{\circ} \mathrm{C}$ for $5 \mathrm{~h}$. Subsequently, the suspension was cooled and centrifuged at $3200 \times g \mathrm{rpm}$ at RT for $15 \mathrm{~min}$. The alkaline supernatant was first neutralized with $2 \mathrm{M}$ acetic acid, and then $\beta$-glucans was precipitated with $45 \mathrm{~mL}$ of ethanol. Proteins removal was achieved by re-dissolving the alcoholic extract in a 3\% acetic acid solution followed by centrifugation at $4000 \times g \mathrm{rpm}$ for $20 \mathrm{~min}$ at RT. The supernatant was neutralized with $2 \mathrm{M}$ $\mathrm{NaOH}$ and subsequently dried. Finally, the dry residue was used to determine the total $\beta$-glucans content.

\section{Analysis of $\beta$-Glucans}

For the determination of $\beta$-glucans, the specific kit of Megazyme International Ireland Ltd. was used, based on the McCleary and Codd [59] method, in which an enzymatic demolition of the $\beta$-glucan up to D-glucose was carried out, measured by a spectrophotometer after addition of reagents that develop the color, of which the absorbance was measured at $510 \mathrm{~nm}$ wavelength.

An aliquot of $200 \mathrm{mg}$ of dry $\beta$-glucan extract was first heated at $40^{\circ} \mathrm{C}$ for $1 \mathrm{~h}$ with $200 \mu \mathrm{L}$ of lichenase enzyme. Then, $40 \mathrm{~mL}$ of double-distilled water was added to the suspension followed by centrifugation at $3000 \times g \mathrm{rpm}$ for $10 \mathrm{~min}$. An aliquot of the extract $(1 \mathrm{~mL})$ was treated with the $\beta$-glucosidase enzyme and incubated at $40{ }^{\circ} \mathrm{C}$ for $15 \mathrm{~min}$. Subsequently, the GOPOD reagent (a mixture of glucose-peroxidase and 4-aminoantipyrin), was added to the sample, and the colorimetric reaction was allowed to take place at $40{ }^{\circ} \mathrm{C}$ for $20 \mathrm{~min}$. The absorbance reading was made at $510 \mathrm{~nm}$ wavelength against the blank 
(acetate buffer solution with GOPOD). Quantitative determination was made using the pure $\beta$-glucan as a standard [59].

\subsection{Statistical Analysis}

Values of three observations were considered for each P. eryngii isolate, all the assays were carried out in triplicate and the results were expressed as mean values ( \pm standard error of mean, SEM). The outcomes were evaluated by using the two-way analysis of variance (ANOVA) with type of isolates as one factor and status of isolates (dry and fresh) as the second factor. Means were separated by least significant differences (LSD) test with a probability level $(p \leq 0.05)$, using SAS software (SAS Institute, Cary, NC, USA, 2015) [60]. Water content, $\beta$-glucans and phenolic compounds, determined on only fresh samples, were subjected to a one-way ANOVA (types of isolates as main factor) using the same software mentioned earlier. An unpaired $t$-test (when the criteria of normality and equal variance are satisfied) was conducted to compare the means of all studied parameters between commercial and wild isolates. When the variances of the $t$-test samples were not equal, the means were compared with a Welch's $t$-test analysis [61].

\section{Results}

The results of the ANOVA test on all studied parameters are reported in Table 2. A significant effect of the type of isolate was found for all parameters. No significant effects of status of the isolate on TPC, antioxidant activity and antiradical power were found, even if samples of fresh mushrooms, subjected to pre-lyophilization, showed a higher polyphenolic content compared to dried ones (Table 2). In addition, a high significant interactive effect between the type of isolate and the status of isolate was found for the TPC (Table 2). This parameter was determined in all P. eryngii samples and showed quite different amounts, which varied from $0.24 \pm 0.01-5.34 \pm 0.05 \mathrm{mg} \mathrm{g}^{-1}$. The maximum and minimum values were reached by fresh sample of the 'V142' commercial isolate and by dry sample of the 'Albino beige chiaro 1094' wild isolate, respectively (Table 3).

Table 2. Analysis of variance of different sources on all studied parameters.

\begin{tabular}{|c|c|c|c|c|c|c|c|c|c|c|}
\hline Source & d.f. & $\begin{array}{c}\text { Total } \\
\text { Polyphenol } \\
\text { Content }\end{array}$ & $\begin{array}{c}\text { Antioxidant } \\
\text { Activity } \\
\text { (ABTS) }\end{array}$ & $\begin{array}{c}\text { Antiradical } \\
\text { Power } \\
\text { (ARP) }\end{array}$ & $\begin{array}{l}\text { Water } \\
\text { Content }\end{array}$ & $\begin{array}{c}\beta- \\
\text { Glucans }\end{array}$ & $\begin{array}{c}\text { Ferulic } \\
\text { Acid }\end{array}$ & $\begin{array}{l}\text { Gallic } \\
\text { Acid }\end{array}$ & ECG & EGCG \\
\hline $\begin{array}{c}\text { Type of } \\
\text { isolate }(\mathrm{T})\end{array}$ & 11 & $* * * 1$ & $* * *$ & $* * *$ & $* * *$ & $* * *$ & $* * *$ & $* * *$ & $* * *$ & $* * *$ \\
\hline $\begin{array}{l}\text { Status of } \\
\text { isolate (S) }\end{array}$ & 1 & NS & NS & NS & - & - & - & - & - & - \\
\hline $\mathrm{T} \times \mathrm{S}$ & 11 & $* * *$ & * & * & - & - & - & - & - & - \\
\hline
\end{tabular}

${ }^{1}$ Significance level indicated by the asterisks: ${ }^{* * *} p<0.001,{ }^{*} p<0.05$, NS-not significant.

Commercial isolates showed higher values of the TPC than wild ones $(p<0.001$ for Welch's $t$-test) (Table 3). Among commercial mushrooms, the lowest value was registered in the dry 'V 160' isolate. Regarding the wild mushrooms, the fresh 'Altamura 1063' and 'Conversano 1250' isolates showed the highest value of TPC (Table 3).

The average values of antioxidant activity (concentration required to obtain a $50 \%$ antioxidant effect, $\mathrm{EC}_{50}$ ) and antiradical power (ARP values compared to $100 \mathrm{~g}$ of dehydrated product) ranged between $2.12-73.25 \pm 0.72 \mathrm{mg} \mathrm{mL}^{-1}$ and from $1.4 \pm 0.03-53.5 \pm 0.37 \%$, respectively. In particular, fresh and dry samples of 'Muro Lucano 139' exhibited the best antioxidant potential, reaching values of $53.5 \pm 0.37 \%$ and $46.9 \pm 0.39 \%$, respectively (Table 3). Among the commercial type isolates of P. eryngii, 'V160' obtained values similar to those recorded for 'Muro Lucano 139' (Table 3). Whereas the lowest values of ARP were reached by fresh and dry P. eryngii samples of 'D+' followed by 'V142', '142 E' and '142 $\mathrm{F}$ ' isolates. 
Table 3. Interactive effect of isolate type and status on polyphenolic content, antioxidant activity (EC 50 of ABTS) and antiradical power (ARP) in twelve P. eryngii isolates from the Basilicata region (Southern Italy).

\begin{tabular}{|c|c|c|c|c|}
\hline Type of Isolate & $\begin{array}{l}\text { Status of } \\
\text { Isolate }\end{array}$ & $\begin{array}{l}\text { Total Polyphenol } \\
\text { Content }\left(\mathrm{mg} \mathrm{g}^{-1}\right)\end{array}$ & $\begin{array}{c}\text { Antioxidant Activity } \\
\left.\text { EC }_{50} \text { of ABTS (mg mL } \mathrm{m}^{-1}\right)\end{array}$ & $\begin{array}{c}\text { Antiradical Power (ARP) } \\
(\%)\end{array}$ \\
\hline \multicolumn{5}{|l|}{ Commercial } \\
\hline \multirow{2}{*}{$' 142 \mathrm{~F}^{\prime}$} & Dry & $2.55 \pm 0.02 \mathrm{i}^{1}$ & $23.81 \pm 0.00 \mathrm{~h}$ & $4.2 \pm 0.06 \mathrm{hi}$ \\
\hline & Fresh & $3.35 \pm 0.04 \mathrm{f}$ & $28.37 \pm 0.37 \mathrm{f}$ & $3.5 \pm 0.05 \mathrm{hi}$ \\
\hline \multirow{2}{*}{ ‘142 E’ } & Dry & $2.85 \pm 0.03 \mathrm{~g}$ & $25.77 \pm 0.01 \mathrm{~g}$ & $3.9 \pm 0.04 \mathrm{hi}$ \\
\hline & Fresh & $3.68 \pm 0.03 \mathrm{e}$ & $31.78 \pm 0.35 \mathrm{e}$ & $3.2 \pm 0.06 \mathrm{hi}$ \\
\hline \multirow{2}{*}{$' \mathrm{D}+{ }^{\prime}$} & Dry & $2.70 \pm 0.09 \mathrm{~h}$ & $60.53 \pm 0.02 b$ & $1.7 \pm 0.03 \mathrm{i}$ \\
\hline & Fresh & $3.56 \pm 0.09 \mathrm{e}$ & $73.25 \pm 0.72 \mathrm{a}$ & $1.4 \pm 0.03 \mathrm{i}$ \\
\hline \multirow{2}{*}{ 'V turbo' } & Dry & $3.30 \pm 0.15 \mathrm{f}$ & $7.67 \pm 0.00 \mathrm{n}$ & $13.0 \pm 0.12 \mathrm{def}$ \\
\hline & Fresh & $4.39 \pm 0.05 c$ & $9.82 \pm 0.38 \mathrm{~m}$ & $10.2 \pm 0.09 \mathrm{fg}$ \\
\hline \multirow{2}{*}{ ‘V142’ } & Dry & $4.05 \pm 0.02 \mathrm{~d}$ & $43.18 \pm 0.01 \mathrm{~d}$ & $2.3 \pm 0.05 \mathrm{hi}$ \\
\hline & Fresh & $5.34 \pm 0.05 \mathrm{a}$ & $52.44 \pm 0.74 \mathrm{c}$ & $1.9 \pm 0.03 \mathrm{hi}$ \\
\hline \multirow{2}{*}{ 'A12' } & Dry & $3.65 \pm 0.02 \mathrm{e}$ & $16.70 \pm 0.00 \mathrm{j}$ & $6.0 \pm 0.08 \mathrm{ghi}$ \\
\hline & Fresh & $4.91 \pm 0.05 \mathrm{~b}$ & $20.35 \pm 0.40 \mathrm{i}$ & $4.9 \pm 0.11 \mathrm{hi}$ \\
\hline \multirow{2}{*}{ ‘V160’ } & Dry & $0.40 \pm 0.01$ op & $2.12 \pm 0.00 \mathrm{q}$ & $47.2 \pm 0.38 b$ \\
\hline & Fresh & $0.53 \pm 0.03 \mathrm{mno}$ & $2.63 \pm 0.08 \mathrm{q}$ & $38.0 \pm 0.33 c$ \\
\hline \multicolumn{5}{|l|}{ Wild } \\
\hline \multirow{2}{*}{ 'Albino 1107' } & Dry & $0.50 \pm 0.00$ no & $6.42 \pm 0.00 \mathrm{op}$ & $15.6 \pm 0.23 \mathrm{de}$ \\
\hline & Fresh & $0.64 \pm 0.01 \mathrm{~lm}$ & $6.01 \pm 0.18 p$ & $16.6 \pm 0.16 \mathrm{~d}$ \\
\hline \multirow{2}{*}{ 'Altamura 1603' } & Dry & $0.86 \pm 0.01 \mathrm{k}$ & $15.40 \pm 0.00 \mathrm{k}$ & $6.5 \pm 0.13 \mathrm{ghi}$ \\
\hline & Fresh & $1.14 \pm 0.03 \mathrm{j}$ & $14.25 \pm 0.351$ & $7.0 \pm 0.14 \mathrm{gh}$ \\
\hline \multirow{2}{*}{ ‘Muro Lucano 139’ } & Dry & $0.50 \pm 0.01 \mathrm{no}$ & $2.13 \pm 0.01 \mathrm{q}$ & $46.9 \pm 0.39 \mathrm{~b}$ \\
\hline & Fresh & $0.62 \pm 0.03 \mathrm{lmn}$ & $1.87 \pm 0.14 \mathrm{q}$ & $53.5 \pm 0.37 a$ \\
\hline \multirow{2}{*}{ ‘Conversano 1250’ } & Dry & $0.72 \pm 0.011$ & $7.74 \pm 0.00 \mathrm{n}$ & $12.9 \pm 0.17 \mathrm{def}$ \\
\hline & Fresh & $0.97 \pm 0.04 \mathrm{k}$ & $7.13 \pm 0.06$ no & $14.0 \pm 0.18 \mathrm{def}$ \\
\hline \multirow{2}{*}{ 'Albino beige chiaro 1094' } & Dry & $0.24 \pm 0.01 \mathrm{q}$ & $9.67 \pm 0.00 \mathrm{~m}$ & $10.4 \pm 0.15$ efg \\
\hline & Fresh & $0.33 \pm 0.02 \mathrm{pq}$ & $9.06 \pm 0.12 \mathrm{~m}$ & $11.0 \pm 0.17 \mathrm{efg}$ \\
\hline \multicolumn{5}{|l|}{ Type of isolates } \\
\hline Commercial & & $3.23 \pm 0.30$ & $28.46 \pm 4.65$ & $10.06 \pm 4.58$ \\
\hline Wild & & $0.65 \pm 0.07$ & $7.97 \pm 1.11$ & $19.44 \pm 3.87$ \\
\hline$t$-test ${ }^{2}$ & & $* * *$ & $* *$ & NS \\
\hline
\end{tabular}

${ }^{1}$ Each value expressed as means \pm SEM ( $n=3$ for interactive effect; $n=21$ for commercial isolates; $n=15$ for wild isolates) in columns not sharing the same letters are significantly different according to Least Significance Difference test $(p \leq 0.05) .{ }^{* *}$, significance at $p<0.01$; ${ }^{* * *}$, significance at $p<0.001 ; \mathrm{NS}$, not significant.

Table 4 shows the effects of type of isolate on water content, $\beta$-glucans and phenolic compounds, which were determined only in fresh samples. The wild P. eryngii isolates were characterized by a higher content of water $(+3.4 \%)$ compared to commercial ones. In detail, 'Albino beige chiaro 1094' and 'Albino 1107' isolates of P. eryngii were the richest in water (Table 4).

The outcomes of $\beta$-glucans analysis emphasized the richness of these compounds within the matrix of different $P$. eryngii isolates. However, it was observed that the wildtype $P$. eryngii isolates had a higher $\beta$-glucanic content compared to the commercial ones. The highest content of $\beta$-glucans was obtained by the 'Albino beige chiaro 1094' wild isolate followed by the 'Muro Lucano 139' one, while the lowest value was reached by the 'V160' commercial isolate (Table 4).

The phenolic profile results showed that the main phenols present were ferulic acid, gallic acid, epicatechingallate (ECG) and epigallocatechigallate (EGCG). The presence of gallic acid and EGCG, founded in all isolates both commercial and wild, could; therefore, motivate the important antioxidant properties exhibited by the P. eryngii isolates studied.

In general, as shown in Table 4, the concentration of the investigated phenolic compounds was superior in the P. eryngii commercial isolates compared to the wild-type ones. Besides, considerable variations were observed between all the P. eryngii isolates investigated. Ferulic acid, gallic acid, ECG and EGCG varied from $0.08 \pm 0.03-1.31 \pm 0.03 \mathrm{mg} \mathrm{g}^{-1}$, 
from $0.14 \pm 0.05-2.43 \pm 0.05 \mathrm{mg} \mathrm{g}^{-1}$, from $0.04 \pm 0.02-0.60 \pm 0.03 \mathrm{mg} \mathrm{g}^{-1}$, and from $0.04 \pm 0.01-0.83 \pm 0.05 \mathrm{mg}_{-} \mathrm{g}^{-1}$, respectively. The ' $\mathrm{V} 142^{\prime}$ commercial isolate recorded the highest values of ferulic acid, gallic acid, epicatechin and epigallocatechigallate. 'Albino beige chiaro 1094' wild-type isolate of $P$. eryngii resulted as being the poorest in phenolic compounds but the richest in $\beta$-glucans and water content (Table 4).

Table 4. Effect of isolate type on water content, $\beta$-glucans and phenolic compounds in twelve P. eryngii isolates from the Basilicata region (Southern Italy).

\begin{tabular}{|c|c|c|c|c|c|c|}
\hline Type of Isolate & $\begin{array}{c}\text { Water Content } \\
(\%)\end{array}$ & $\begin{array}{l}\beta \text {-Glucans } \\
\left(g \_100 g^{-1}\right)\end{array}$ & $\begin{array}{l}\text { Ferulic Acid } \\
\left(\mathrm{mg}_{-} \mathrm{g}^{-1}\right)\end{array}$ & $\begin{array}{l}\text { Gallic Acid } \\
\left(m g \_g^{-1}\right)\end{array}$ & $\begin{array}{c}\text { ECG } \\
\left(\mathrm{mg}_{-} \mathrm{g}^{-1}\right)\end{array}$ & $\begin{array}{c}\text { EGCG } \\
\left(\mathrm{mg}_{-} \mathrm{g}^{-1}\right)\end{array}$ \\
\hline \multicolumn{7}{|l|}{ Commercial } \\
\hline$' 142 \mathrm{~F}^{\prime}$ & $83.2 \pm 0.11 \mathrm{f}^{1}$ & $23.4 \pm 0.72 \mathrm{~d}$ & $0.77 \pm 0.04 c$ & $1.32 \pm 0.02 c$ & $0.34 \pm 0.05 \mathrm{~cd}$ & $0.42 \pm 0.09 c$ \\
\hline '142 E’ & $85.2 \pm 0.06 \mathrm{~d}$ & $21.6 \pm 0.40 \mathrm{de}$ & $0.87 \pm 0.05 c$ & $1.54 \pm 0.01 \mathrm{bc}$ & $0.47 \pm 0.06 \mathrm{abc}$ & $0.54 \pm 0.06 \mathrm{bc}$ \\
\hline${ }^{\prime} \mathrm{D}+{ }^{\prime}$ & $85.6 \pm 0.17 \mathrm{~cd}$ & $19.3 \pm 0.70 \mathrm{fg}$ & $0.86 \pm 0.03 c$ & $1.41 \pm 0.03 c$ & $0.27 \pm 0.05 \mathrm{de}$ & $0.54 \pm 0.05 b c$ \\
\hline 'V turbo' & $81.9 \pm 0.23 \mathrm{~g}$ & $20.8 \pm 0.77$ ef & $1.04 \pm 0.07 \mathrm{~b}$ & $1.75 \pm 0.03 \mathrm{~b}$ & $0.45 \pm 0.07 \mathrm{bc}$ & $0.52 \pm 0.10 b c$ \\
\hline 'V142' & $82.3 \pm 0.17 \mathrm{~g}$ & $18.5 \pm 0.86 \mathrm{~g}$ & $1.31 \pm 0.03 \mathrm{a}$ & $2.43 \pm 0.05 a$ & $0.54 \pm 0.02 \mathrm{ab}$ & $0.83 \pm 0.05 a$ \\
\hline 'A12' & $83.1 \pm 0.12 \mathrm{f}$ & $22.6 \pm 0.63 \mathrm{de}$ & $1.20 \pm 0.08 \mathrm{a}$ & $2.14 \pm 0.33 \mathrm{a}$ & $0.60 \pm 0.03 a$ & $0.67 \pm 0.09 \mathrm{ab}$ \\
\hline$' \mathrm{~V} 160 '$ & $84.7 \pm 0.06 \mathrm{e}$ & $12.8 \pm 0.43 \mathrm{~h}$ & $0.10 \pm 0.03 \mathrm{de}$ & $0.14 \pm 0.05 \mathrm{e}$ & $0.07 \pm 0.03 \mathrm{f}$ & $0.08 \pm 0.01 \mathrm{~d}$ \\
\hline \multicolumn{7}{|l|}{ Wild } \\
\hline 'Albino 1107' & $87.4 \pm 0.11 \mathrm{a}$ & $29.7 \pm 0.82 c$ & $0.12 \pm 0.03 \mathrm{de}$ & $0.26 \pm 0.08 \mathrm{de}$ & $0.07 \pm 0.04 \mathrm{f}$ & $0.11 \pm 0.05 \mathrm{~d}$ \\
\hline 'Altamura 1603' & $85.8 \pm 0.17 c$ & $31.6 \pm 0.53 b c$ & $0.12 \pm 0.05 \mathrm{de}$ & $0.25 \pm 0.04 \mathrm{de}$ & $0.08 \pm 0.01 \mathrm{f}$ & $0.09 \pm 0.03 \mathrm{~d}$ \\
\hline 'Muro Lucano 139’ & $85.7 \pm 0.06 c$ & $32.5 \pm 0.84 \mathrm{ab}$ & $0.20 \pm 0.05 \mathrm{de}$ & $0.51 \pm 0.06 \mathrm{~d}$ & $0.11 \pm 0.05 \mathrm{f}$ & $0.16 \pm 0.06 \mathrm{~d}$ \\
\hline 'Conversano 1250' & $86.6 \pm 0.12 b$ & $21.3 \pm 0.60 \mathrm{e}$ & $0.23 \pm 0.03 \mathrm{~d}$ & $0.41 \pm 0.06 \mathrm{de}$ & $0.16 \pm 0.05$ ef & $0.13 \pm 0.04 \mathrm{~d}$ \\
\hline $\begin{array}{l}\text { 'Albino beige } \\
\text { chiaro } 1094 \text { ' }\end{array}$ & $87.5 \pm 0.17 \mathrm{a}$ & $33.8 \pm 0.70 \mathrm{a}$ & $0.08 \pm 0.03 \mathrm{e}$ & $0.15 \pm 0.07 \mathrm{e}$ & $0.04 \pm 0.02 \mathrm{f}$ & $0.04 \pm 0.00 \mathrm{~d}$ \\
\hline \multicolumn{7}{|l|}{ Type of isolates } \\
\hline Commercial & $83.71 \pm 0.30$ & $19.86 \pm 0.76$ & $0.88 \pm 0.08$ & $1.53 \pm 0.16$ & $0.39 \pm 0.04$ & $0.51 \pm 0.05$ \\
\hline Wild & $86.60 \pm 0.21$ & $29.78 \pm 1.22$ & $0.15 \pm 0.02$ & $0.32 \pm 0.04$ & $0.09 \pm 0.02$ & $0.11 \pm 0.02$ \\
\hline$t$-test ${ }^{2}$ & ** & $* *$ & $* *$ & $* *$ & $* *$ & $* *$ \\
\hline
\end{tabular}

${ }^{1}$ Each value expressed as mean \pm SE $(n=3$ for type of isolate effect; $n=21$ for commercial isolates; $n=15$ for wild isolates) in columns not sharing the same letters are significantly different according to least significant difference test $(p \leq 0.05){ }^{2 * *}$, significance at $p<0.01$; ECG = epicatechin; EGCG = epigallocatechallallate.

\section{Discussion}

Edible mushrooms (EMs) are important sources of nutrients for the human diet, being utilized worldwide, and contain many chemical compounds with several pharmacological, medicinal, cosmetic and biocontrol properties $[5,13,16,62]$. Results from our study, on various $P$. eryngii isolates, both wild and cultivated types, from the Basilicata region, surely added further knowledge on this fungi and also generally agree with the outcomes of several studies previously performed on EMs. Such as the earlier work of Cheung et al. [63], who analyzed the antioxidant activity and the total phenols in two EMs Shiitake and straw mushrooms and showed that they may have potential as antioxidants. In addition, the present work furnished similar results as the studies of Oke and Aslim [64], who examined the phenolic compositions and antioxidative, protective and cytotoxic effects of $P$. eryngii and Auricularia auricula-judae and revealed that this fungi are able, based on their compounds, to protect against oxidative cell damage and can be used as a potential source of natural antioxidants.Furthermore, the results very much agree with the very recent studies of Bahadori et al. [65] who investigated the metal concentration, phenols and antioxidant activity in two negligible wild mushrooms Melanoleuca cognata and $M$. stridula and demonstrated that these types of EMs can have good nutritional value and also provide important health benefits.

Particularly, new and useful knowledge of the medicinal value of the P. eryngii mushroom has arisen from the outcomes of this study, showing that the polyphenols reached, on average, higher concentrations in the commercial isolates. Since the phenolic content has always been higher in the fresh mushroom samples compared to the dry ones, it can 
be hypothesized that the heat could determine a partial degradation/loss of the phenolic compounds during the drying process. From the analysis of the phenolic profile it has emerged that ferulic acid, gallic acid, epicatechingallate (ECG) and epigallocatechigallate (EGCG) are the most present compounds. Of particular interest is the presence of gallic acid and EGCG, which confirms the remarkable antioxidant properties of all P. eryngii isolates studied. Especially, the wild-type 'Muro Lucano 139', 'Albino 1107' and 'Conversano 1250' $P$. eryngii isolates showed a remarkably high antioxidant activity.

Apart from polyphenols, other important functional components had been isolated from EMs, like $\beta$-glucans, which have demonstrated them to have hypocholesterolemic, antidiabetic and anticarcinogenic properties as well as positive effects on the immune system [66-68]. The mushroom species most rich in $\beta$-glucan were found to be Lentinus edodes and some members of the Pleurotus genus, such as P. ostreatus and P. eryngii [69].

P. eryngii contain, in general, $85-90 \%$ moisture, $11-12$ g_100 $\mathrm{g}^{-1}$ dried mushroom protein content, 39-40 g_100 g ${ }^{-1}$ carbohydrates, 7-8 g_100 g ${ }^{-1}$ lipids, 28-29 g_100 g ${ }^{-1}$ fibers and $4-5 g_{-} 100 \mathrm{~g}^{-1}$ minerals [70]. The water content of the P. eryngii isolates from this study was similar compared to what has been reported by other authors $[70,71]$ and also match with the outcomes of the investigation of Gezer et al. [72], which showed that wild mushrooms had a low dry matter content but a high value of water, fiber and beta-glucans content.

Moreover, the present work integrates well among the only few studies reported so far that dealt with comparisons of bioactive compounds (mainly glucans) between cultivated and wild mushrooms. For example, the work of Sari et al. [71], who showed that many wild species, like Trametes versicolor and Boletus edulis, had a higher $\beta$-glucans content and also revealed that cultivated mushrooms had a range of $\beta$-glucans content between 8.60-26.93 g_100 $\mathrm{g}^{-1}$, while P. eryngii had a $\beta$-glucans value of $15.32 \mathrm{~g}_{-} 100 \mathrm{~g}^{-1}$ [71]. In addition, the work of Butkup et al. [73], who evaluated the $\beta$-glucan content of twenty-five wild edible mushrooms from Northeastern Thailand, showed that Volvariella volvacea, a gilled mushroom, reached the highest content ( $\left.34.4 \mathrm{~g}_{-} 100 \mathrm{~g}^{-1}\right)$, while Alpova trappei, a puffball mushroom, obtained the lowest one $\left(0.62 \mathrm{~g}_{-} 100 \mathrm{~g}^{-1}\right)$. In the present study, the $\beta$-glucans content, known for its hypocholesterolemic activity, was also of great significance and its concentration was, on average, elevated in wild-type isolates, being the highest for 'Albino beige chiaro 1094' than the commercial ones.

Research on wild edible fungi (WEF) compared to commercial types were earlier performed by Barros et al. [11], who showed that the wild mushroom species contained higher amounts of protein and lower fat concentrations. Besides, the $\alpha$-Tocopherol was detected in higher amounts in the wild species along with a higher content of phenols, but a lower content of ascorbic acid, than commercial mushrooms. Wang et al. [74] indicated that wild mushrooms accumulate more macronutrients and micronutrients and they are rich mainly in potassium, phosphorus, calcium, magnesium, sodium and iron. Similarly, in our study an elevated bioactive substances concentration was found especially in the WEF investigated, identical to what was reported by Palazzolo et al. [44], who analyzed five WEF collected from Sicily (Fistulina hepatica, Infundibulicybe geotropa, Laetiporus sulphureus, Macrolepiota procera var. procera and Suillus granulatus) and reported a high content of vitamin B12 and riboflavin presence. These latter results suggested that the WEF could be very valuable natural products and; therefore, including them in many diets is certainly highly beneficial [44,75-77].

Some investigations focusing on P. eryngii and P. nebrodensis (Quél., 1886) furnished more information about these highly appreciated mushrooms and revealed their important nutritional and medicinal value [78-80]. Thus, further studies examining some P. nebrodensis isolates along with a few more of the P. eryngii ones could be useful and; therefore, will be planned. 


\section{Conclusions}

The "Cardoncello" mushroom, an excellent product in gastronomy, is considered a food of high nutraceutical value, thanks to its strong antioxidant properties and elevated content in bioactive compounds, such as total phenolic and beta-glucan content.

On the basis of the results from this study, it can be concluded that type of mushrooms (commercial and wild) influenced both the phenolic compounds and $\beta$-glucans content. In particular, cultivated $P$. eryngii isolates showed a higher content of TPC, ferulic acid, gallic acid, epicatechingallate and epigallocatechigallate, while wild mushrooms were characterized by a superior content of $\beta$-glucans. This latter outcome suggested that wild $P$. eryngii isolates represent a very good source of beneficial compounds to human health.

However, further investigations, taking into account a greater number of "Cardoncello" isolates, are needed to generalize better and apply the results of the present study.

The results from future studies on WEF can furnish important and useful data for the production of novel active foods with high nutritional value and wide and diverse medicinal applications in mycotherapy.

Author Contributions: Conceptualization: V.C., I.C., S.M.M., L.C.; methodology: A.C.; software: L.C., D.C.; validation: all authors contributed equally to the validation of the work; formal analysis: A.B.; investigation: A.B., A.C., V.C., S.M.M., L.C., D.C.; data curation: V.C., A.C., I.C., S.M.M., L.C.; writing-original draft preparation: S.M.M., A.C., V.C., I.C.; writing-review and editing: S.M.M., V.C., I.C., A.C., L.C., D.C.; supervision: I.C., V.C., A.C. All authors have read and agreed to the published version of the manuscript.

Funding: This research received no external funding.

Institutional Review Board Statement: Not applicable.

Informed Consent Statement: Not applicable.

Data Availability Statement: The data presented in this study are available on request from the corresponding author.

Acknowledgments: The authors thank Donato Aicale of Cardopan Company, Tolve-Potenza (Italy) for his contribution to the research by providing the commercial "Cardoncello" isolates.

Conflicts of Interest: The authors declare no conflict of interest.

\section{References}

1. Mattila, P.; Könkö, K.; Eurola, M.; Pihlava, J.-M.; Astola, J.; Vahteristo, L.; Hietaniemi, V.; Kumpulainen, J.; Valtonen, M.; Piironen, V. Contents of Vitamins, Mineral Elements, and Some Phenolic Compounds in Cultivated Mushrooms. J. Agric. Food Chem. 2001, 49, 2343-2348. [CrossRef]

2. Manzi, P.; Marconi, S.; Aguzzi, A.; Pizzoferrato, L. Commercial mushrooms: Nutritional quality and effect of cooking. Food Chem. 2004, 84, 201-206. [CrossRef]

3. Feeney, M.J.; Miller, A.M.; Roupas, P. Mushrooms-Biologically Distinct and Nutritionally Unique. Nutr. Today 2014, 49, 301-307. [CrossRef]

4. Gargano, M.L.; Van Griensven, L.J.L.D.; Isikhuemhen, O.S.; Lindequist, U.; Venturella, G.; Wasser, S.P.; Zervakis, G.I. Medicinal mushrooms: Valuable biological resources of high exploitation potential. Plant Biosyst.Int. J. Deal. Asp. Plant Biol. 2017, 151, 548-565. [CrossRef]

5. Reis, F.S.; Martins, A.; Vasconcelos, M.H.; Morales, P.; Ferreira, I.C.F.R. Functional foods based on extracts or compounds derived from mushrooms. Trends Food Sci. Technol. 2017, 66, 48-62. [CrossRef]

6. Castronuovo, D.; Mang, S.M.; Becce, A.; Candido, V.; Cardone, L.; Camele, I. Morphological and productivity comparison between commercial and wild isolates of Pleurotuseryngii (D.C.: Fr.) Quél. Ital. J. Agron. 2019, 14, 170-175. [CrossRef]

7. Feeney, M.J.; Dwyer, J.; Hasler-Lewis, C.M.; Milner, J.A.; Noakes, M.; Rowe, S.; Wach, M.; Beelman, R.B.; Caldwell, J.; Cantorna, M.T.; et al. Mushrooms and Health Summit Proceedings. J. Nutr. 2014, 144, 1128S-1136S. [CrossRef] [PubMed]

8. Pohleven, J.; Korošec, T.; Gregori, A. Medicinal Mushrooms. MycoMedica, d. o. o., Podkoren 72, 4280 Kranjska Gora, Slovenia, 2016. Available online: www.goba.eu (accessed on 11 December 2020).

9. Chang, S.T.; Buswell, J.A. Mushrooms nutraceuticals. World J. Microbiol. Biotech. 1996, 12, 473-476. [CrossRef] [PubMed]

10. Gunde-Cimerman, N. Medicinal Value of the Genus Pleurotus (Fr.) P.Karst. (Agaricales s.l., Basidiomycetes). Int. J. Med. Mushrooms 1999, 1, 69-80. [CrossRef] 
11. Barros, L.; Cruz, T.; Baptista, P.; Estevinho, L.M.; Ferreira, I.C. Wild and commercial mushrooms as source of nutrients and nutraceuticals. Food Chem. Toxicol. 2008, 46, 2742-2747. [CrossRef]

12. Cheung, P.C.K. The nutritional and health benefits of mushrooms-Review. Nutrition Bull. 2010, 35, 292-299. [CrossRef]

13. Lindequist, U.; Niedermeyer, T.H.J.; Jülich, W.-D. The Pharmacological Potential of Mushrooms. Evidence Based Complement. Altern. Med. 2005, 2, 285-299. [CrossRef]

14. Chaturvedi, V.K.; Agarwal, S.; Gupta, K.K.; Ramteke, P.W.; Singh, M.P. Medicinal mushroom: Boon for therapeutic applications. 3 Biotech 2018, 8, 334. [CrossRef] [PubMed]

15. Guzmán, G. Genus Pleurotus (Jacq.: Fr.) P. Kumm. (Agaricomycetideae): Diversity, Taxonomic Problems, and Cultural and Traditional Medicinal Uses. Int. J. Med. Mushrooms 2000, 2, 29. [CrossRef]

16. Kothari, D.; Patel, S.; Kim, S.-K. Anticancer and other therapeutic relevance of mushroom polysaccharides: A holistic appraisal. Biomed. Pharmacother. 2018, 105, 377-394. [CrossRef] [PubMed]

17. Souilem, F.; Fernandes, Â.; Calhelha, R.C.; Barreira, J.C.; Barros, L.; Skhiri, F.; Martins, A.; Ferreira, I.C. Wild mushrooms and their mycelia as sources of bioactive compounds: Antioxidant, anti-inflammatory and cytotoxic properties. Food Chem. 2017, 230, 40-48. [CrossRef]

18. Wasser, S.P. Medicinal Mushroom Science: History, Current Status, Future Trends, and Unsolved Problems. Int. J. Med. Mushrooms 2010, 12, 1-16. [CrossRef]

19. Borchers, A.T.; Keen, C.L.; Gershwin, M.E. Mushrooms, Tumors, and Immunity: An Update. Exp. Biol. Med. 2004, 229, 393-406. [CrossRef]

20. Patel, Y.; Naraian, R.; Singh, V.K. Medicinal properties of Pleurotus species (oyster mushroom): A review. World J. Fungal Plant Biol. 2012, 3, 1-12.

21. Hossain, S.; Hashimoto, M.; Choudhury, E.K.; Alam, N.; Hussain, S.; Hasan, M.; Choudhury, S.K.; Mahmud, I. Dietary mushroom (Pleurotus ostreatus) ameliorates atherogenic lipid in hypercholesterolaemic rats. Clin. Exp. Pharmacol. Physiol. 2003, 30, 470-475. [CrossRef]

22. De Silva, D.D.; Rapior, S.; Hyde, K.D.; Bahkali, A.H. Medicinal mushrooms in prevention and control of diabetes mellitus. Fungal Divers. 2012, 56, 1-29. [CrossRef]

23. Bello, M.; Oluwamukomi, O.; Enujiugha, V. Anti-diabetic activity of three species of oyster mushroom. Annu. Food Sci. Technol. 2017, 18, 247-254.

24. Balaji, P.; Madhanraj, R.; Rameshkumar, K.; Veeramanikandan, V.; Eyini, M.; Arun, A.; Thulasinathan, B.; Al Farraj, D.; Elshikh, M.; Alokda, A.; et al. Evaluation of antidiabetic activity of Pleurotus pulmonarius against streptozotocin-nicotinamide induced diabetic wistar albino rats. Saudi J. Biol. Sci. 2020, 27, 913-924. [CrossRef] [PubMed]

25. Yoshioka, Y.; Ikekawa, T.; Noda, M.; Fukuoka, F. Studies on Antitumor Activity of Some Fractions from Basidiomyces. I. An Antitumor Acidic Polysaccharide Fraction of P. ostreatus (Fr.) QUEL. Chem. Pharm. Bull. 1972, 20, 1175-1180. [CrossRef] [PubMed]

26. Phan, C.-W.; David, P.; Naidu, M.; Wong, K.-H.; Sabaratnam, V. Therapeutic potential of culinary-medicinal mushrooms for the management of neurodegenerative diseases: Diversity, metabolite, and mechanism. Crit. Rev. Biotechnol. 2013, 35, 355-368. [CrossRef]

27. Chong, P.S.; Fung, M.-L.; Wong, K.H.; Lim, L.W. Therapeutic Potential of Hericium erinaceus for Depressive Disorder. Int. J. Mol. Sci. 2019, 21, 163. [CrossRef]

28. Valverde, M.E.; Hernández-Pérez, T.; Paredes-López, O. Edible Mushrooms: Improving Human Health and Promoting Quality Life. Int. J. Microbiol. 2015, 2015, 1-14. [CrossRef]

29. Rathore, H.; Prasad, S.; Capri, M.; Tiwari, A.; Sharma, S. Medicinal importance of mushroom mycelium: Mechanisms and applications. J. Funct. Foods 2019, 56, 182-193. [CrossRef]

30. Aida, F.; Shuhaimi, M.; Yazid, M.; Maaruf, A. Mushroom as a potential source of prebiotics: A review. Trends Food Sci. Technol. 2009, 20, 567-575. [CrossRef]

31. Jeong, S.C.; Jeong, Y.T.; Yang, B.K.; Islam, R.; Koyyalamudi, S.R.; Pang, G.; Cho, K.Y.; Song, C.H. White button mushroom (Agaricus bisporus) lowers blood glucose and cholesterol levels in diabetic and hypercholesterolemic rats. Nutr. Res. 2010, 30, 49-56. [CrossRef]

32. Bajaj, M.; Vadhera, S.; Brar, A.P.; Soni, G.L. Role of oyster mushroom (Pleurotus florida) as hypocholesterolemic/antiatherogenic agent. Indian J. Exp. Boil. 1997, 35, 1070-1075.

33. Bobek, P.; Ozdín, L.; Kuniak, L.; Hromadová, M. [Regulation of cholesterol metabolism with dietary addition of oyster mushrooms (Pleurotus ostreatus) in rats with hypercholesterolemia]. Cas. Lek. Ceskych 1997, 136, 186-190.

34. Bobek, P.; Ozdín, L.; Galbavý, S. Dose- and time-dependent hypocholesterolemic effect of oyster mushroom (Pleurotus ostreatus) in rats. Nutrition 1998, 14, 282-286. [CrossRef]

35. Jesenak, M.; Hrubisko, M.; Majtan, J.; Rennerova, Z.; Banovcin, P. Anti-allergic Effect of Pleuran ( $\beta$-glucan from Pleurotus ostreatus) in Children with Recurrent Respiratory Tract Infections. Phytother. Res. 2013, 28, 471-474. [CrossRef]

36. Bohn, J.A.; BeMiller, J.N. (1-3)- $\beta$-D-glucans as biological response modifiers: A review of structure-functional activity relationships. Carbohydr. Polym. 1995, 28, 3-14. [CrossRef]

37. Vetvicka, V.; Yvin, J.-C. Effects of marine $\beta-1,3$ glucan on immune reactions. Int. Immunopharmacol. 2004, 4, 721-730. [CrossRef] 
38. Wang, H.; $\mathrm{Ng}, \mathrm{T}$. Isolation of a Novel Ubiquitin-like Protein from Pleurotus ostreatus Mushroom with Anti-Human Immunodeficiency Virus, Translation-Inhibitory, and Ribonuclease Activities. Biochem. Biophys. Res. Commun. 2000, 276, 587-593. [CrossRef]

39. Zhang, M.; Cheung, P.C.; Ooi, V.E.; Zhang, L. Evaluation of sulfated fungal $\beta$-glucans from the sclerotium of Pleurotus tuber-regium as a potential water-soluble anti-viral agent. Carbohydr. Res. 2004, 339, 2297-2301. [CrossRef]

40. Mizuno, T.; Saito, H.; Nishitoba, T.; Kawagishi, H. Antitumor-active substances from mushrooms. Food Rev. Int. 1995, $11,23-61$. [CrossRef]

41. Endo, A. Chemistry, biochemistry, and pharmacology of HMG-CoA reductase inhibitors. J. Mol. Med. 1988, 66, 421-427. [CrossRef]

42. Agrahar-Murugkar, D.; Subbulakshmi, G. Nutritional value of edible wild mushrooms collected from the Khasi hills of Meghalaya. Food Chem. 2005, 89, 599-603. [CrossRef]

43. Díez, V.; Alvarez, A. Compositional and nutritional studies on two wild edible mushrooms from northwest Spain. Food Chem. 2001, 75, 417-422. [CrossRef]

44. Palazzolo, E.; Gargano, M.L.; Venturella, G. The nutritional composition of selected wild edible mushrooms from Sicily (southern Italy). Int. J. Food Sci. Nutr. 2011, 63, 79-83. [CrossRef] [PubMed]

45. Obodai, M.; Ferreira, I.C.; Fernandes, A.; Barros, L.; Mensah, D.L.N.; Dzomeku, M.; Urben, A.F.; Prempeh, J.; Takli, R.K. Evaluation of the Chemical and Antioxidant Properties of Wild and Cultivated Mushrooms of Ghana. Molecules 2014, 19, 19532-19548. [CrossRef] [PubMed]

46. Carbonero, E.R.; Gracher, A.H.P.; Smiderle, F.R.; Rosado, F.R.; Sassaki, G.L.; Gorin, P.A.; Iacomini, M. A $\beta$-glucan from the fruit bodies of edible mushrooms Pleurotus eryngii and Pleurotus ostreatus. Carbohydr. Polymers 2006, 66, $252-257$.

47. Ren, L.; Perera, C.; Hemar, Y. Antitumor activity of mushroom polysaccharides: A review. Food Funct. 2012, 3, 1118-1130. [CrossRef]

48. Golak-Siwulska, I.; Kałużewicz, A.; Spiżewski, T.; Siwulski, M.; Sobieralski, K. Bioactive compounds and medicinal properties of Oyster mushrooms (Pleurotus sp.). Folia Hortic. 2018, 30, 191-201. [CrossRef]

49. Folin, O.; Ciocalteu, V. Om Tyrosine and Tryptophane Determinations in Proteins. J. Biol. Chem. 1927, 73, 627-650. [CrossRef]

50. Singleton, V.L.; Orthofer, R.; Lamuela-Raventós, R.M.; Lester, P. Analysis of total phenols and other oxidation substrates and antioxidants by means of Folin-Ciocalteu reagent. Methods Enzymol. 1999, 299, 152-178.

51. Gasecka, M.; Mleczek, M.; Siwulski, M.; Niedzielski, P. Phenolic composition and antioxidant properties of Pleurotus ostreatus and Pleurotus eryngii enriched with selenium and zinc. Eur. Food Res. Technol. 2016, 242, 723-732. [CrossRef]

52. Tsao, R.; Yang, R.; Young, J.-C.; Zhu, H. Polyphenolic profiles in eight apple cultivars using high-performance liquid chromatography (HPLC). J. Agric. Food Chem. 2003, 51, 6347-6353. [CrossRef]

53. Zięba, P.; Kała, K.; Włodarczyk, A.; Szewczyk, A.; Kunicki, E.; Sękara, A.; Muszyńska, B. Selenium and Zinc Biofortification of Pleurotus eryngii Mycelium and Fruiting Bodies as a Tool for Controlling Their Biological Activity. Molecules 2020, 25, 889. [CrossRef]

54. Miller, N.J.; Rice-Evans, C.A. Factors Influencing the Antioxidant Activity Determined by the ABTS•+Radical Cation Assay. Free. Radic. Res. 1997, 26, 195-199. [CrossRef]

55. Zeng, X.; Suwandi, J.; Fuller, J.; Doronila, A.; Ng, K. Antioxidant capacity and mineral contents of edible wild Australian mushrooms. Food Sci. Technol. Int. 2012, 18, 367-379. [CrossRef] [PubMed]

56. Li, S.; Shah, N.P. Characterization, antioxidative and bifidogenic effects of polysaccharides from Pleurotus eryngii after heat treatments. Food Chem. 2016, 197, 240-249. [CrossRef]

57. Yu, E.-J.; Han, S.-R.; Kim, K.-H.; Park, B.-R.; Lim, K.-O.; Oh, T.-J. Antibacterial and Antioxidant Activity of Pleurotus eryngii Extracts. Indian J. Public Heal. Res. Dev. 2018, 9, 2206. [CrossRef]

58. Lee, J.-N.; Lee, D.-Y.; Ji, I.-H.; Kim, G.-E.; Kim, H.N.; Sohn, J.; Kim, S.; Kim, C.-W. Purification of Soluble $\beta$-Glucan with Immune-enhancing Activity from the Cell Wall of Yeast. Biosci. Biotechnol. Biochem. 2001, 65, 837-841. [CrossRef]

59. McCleary, B.V.; Codd, R. Measurement of $(1 \rightarrow 3),(1 \rightarrow 4)-\beta$-D-glucan in barley and oats: A streamlined enzymic procedure. J. Sci. Food Agric. 1991, 55, 303-312. [CrossRef]

60. SAS Unstitute Inc. SAS Visual Analytics 7.2: User's Guide; SAS Institute Inc.: Cary, NC, USA, 2008; pp. $27513-27514$.

61. Welch, B.L. The Generalization of 'Student's' Problem when Several Different Population Variances are Involved. Biometrika 1947, 34, 28. [CrossRef] [PubMed]

62. Merkuri, J.; Mang, S.M.; Camele, I.; Cara, M.; Rana, G.L. Molecular identification and artificial cultivation of a wild isolate of oyster mushroom in Albania. Ital. J. Agron. 2015, 11, 35. [CrossRef]

63. Cheung, L.; Cheung, P.C.; Ooi, V.E. Antioxidant activity and total phenolics of edible mushroom extracts. Food Chem. 2003, 81, 249-255. [CrossRef]

64. Oke, F.; Aslim, B. Protective effect of two edible mushrooms against oxidative cell damage and their phenolic composition. Food Chem. 2011, 128, 613-619. [CrossRef]

65. Bahadori, M.B.; Sarikurkcu, C.; Yalcin, O.U.; Cengiz, M.; Gungor, H. Metal concentration, phenolics profiling, and antioxidant activity of two wild edible Melanoleuca mushrooms (M. cognata and M. stridula). Microchem. J. 2019, 150, 104172. [CrossRef]

66. Manzi, P.; Pizzoferrato, L. Beta-glucans in edible mushrooms. Food Chem. 2000, 68, 315-318. [CrossRef] 
67. Synytsya, A.; Míčková, K.; Synytsya, A.; Jablonský, I.; Spěváček, J.; Erban, V.; Kováříková, E.; Čopíková, J. Glucans from fruit bodies of cultivated mushrooms Pleurotus ostreatus and Pleurotus eryngii: Structure and potential prebiotic activity. Carbohydr. Polym. 2009, 76, 548-556. [CrossRef]

68. Minato, K.-I.; Ohara, A.; Mizuno, M. A Proinflammatory Effect of the $\beta$-Glucan from Pleurotus cornucopiae Mushroom on Macrophage Action. Mediat. Inflamm. 2017, 2017, 1-9. [CrossRef]

69. Zhu, F.; Du, B.; Bian, Z.; Xu, B. Beta-glucans from edible and medicinal mushrooms: Characteristics, physicochemical and biological activities. J. Food Compos. Anal. 2015, 41, 165-173. [CrossRef]

70. Khan, A.; Tania, M. Nutritional and Medicinal Importance of Pleurotus Mushrooms: An Overview. Food Rev. Int. 2012, 28, 313-329. [CrossRef]

71. Sari, M.; Prange, A.; Lelley, J.I.; Hambitzer, R. Screening of beta-glucan contents in commercially cultivated and wild growing mushrooms. Food Chem. 2017, 216, 45-51. [CrossRef]

72. Gezer, K.; Kaygusuz, O.; Herken, E.N.; Dodurga, Y.; Koizhaiganova, M.; Seçme, M. Evaluation of the nutritional composition of wild edible mushroom Agaricus lanipes (F.H. Møller \& Jul. Schäff.) Hlaváček. Bangladesh J. Bot. 2016, 45, 161-166.

73. Butkhup, L.; Samappito, W.; Jorjong, S. Evaluation of bioactivities and phenolic contents of wild edible mushrooms from north-eastern Thailand. Food Sci. Biotechnol. 2018, 27, 193-202. [CrossRef]

74. Wang, X.-M.; Zhang, J.; Wu, L.-H.; Zhao, Y.-L.; Li, T.; Li, J.-Q.; Wang, Y.-Z.; Liu, H.-G. A mini-review of chemical composition and nutritional value of edible wild-grown mushroom from China. Food Chem. 2014, 151, 279-285. [CrossRef]

75. Ferreira, I.C.; Vaz, J.A.; Vasconcelos, M.H.; Martins, A. Compounds from Wild Mushrooms with Antitumor Potential. Anti Cancer Agents Med. Chem. 2010, 10, 424-436. [CrossRef] [PubMed]

76. Ferreira, I.C.F.R.; Barros, L.; Abreu, R.M.V. Antioxidants in Wild Mushrooms. Curr. Med. Chem. 2009, 16, 1543-1560. [CrossRef] [PubMed]

77. Yildirim, U.C.; Turkoglu, S.; Yildirim, N.; Ince, O.K. Antioxidant properties of wild edible mushroom Pleurotus eryngii collected from Tunceli province of Turkey. Dig. J. Nanomater. Biostruct. 2012, 7, 1647-1654.

78. Rana, G.L.; Sisto, D.; Mang, S.M.; Candido, V. Preliminary studies on productivity of white Pleurotus eryngii isolates in protected cultivation. Ital. J. Agron. 2013, 8, 6. [CrossRef]

79. Venturella, G.; Zervakis, G.I.; Polemis, E.; Gargano, M.L. Taxonomic Identity, Geographic Distribution, and Commercial Exploitation of the Culinary-Medicinal Mushroom Pleurotus nebrodensis (Basidiomycetes). Int. J. Med. Mushrooms 2016, 18, 59-65. [CrossRef] [PubMed]

80. Alam, N.; Yoon, K.; Lee, J.; Lee, M.; Lee, T. Pleurotus nebrodensis Ameliorates Atherogenic Lipid and Histological Function in Hypercholesterolemic Rats. Int. J. Pharmacol. 2011, 7, 455-462. [CrossRef] 